\title{
An interictal study of partial epilepsy using positron emission tomography and the oxygen -15 inhalation technique
}

\author{
S BERNARDI, ${ }^{*}$ MR TRIMBLE, $\dagger$ RSJ FRACKOWIAK, ${ }^{*}$ RJS WISE, ${ }^{*}$ T JONES* \\ From the National Hospitals for Nervous Diseases, $\dagger$ Queen Square, and the MRC Cylcotron Unit, \\ Hammersmith Hospital, ${ }^{*}$ Du Cane Road, London, UK.
}

SUMMARY Data from ten patients with complex partial seizures who underwent positron emission tomography using the 15-0 inhalation technique are presented. Decreased flow and metabolism are noted in the hemisphere ipsilateral to the EEG focus, but, in patients with unilateral foci, bilateral changes in temporal cortex are detected. Other areas maximally affected include the basal ganglia, and the cerebellum. The possible role of anticonvulsant drugs in these findings is discussed.

Several methods have been employed to study cerebral blood flow and metabolism in epilepsy. Recently Kuhl and co-workers ${ }^{1}$ have reported studies with positron emission tomography using the 18-fluoro-deoxy-glucose technique to assess metabolism, and have demonstrated focal decreases of glucose uptake during the interictal period in partial epilepsy. In contrast, during the ictus, increases are noted in the same areas, in keeping with the experimental literature that during seizures oxygen comsumption, cerebral blood flow and glucose metabolism increase significantly. ${ }^{2}$

In this study we report preliminary data obtained using a positron emission scanner, and the oxygen 15 inhalation technique developed at the Hammersmith Hospital, ${ }^{3}$ in patients with partial seizures. The studies were all carried out interictally, and the results of regional cerebral blood flow (rCBF), regional oxygen metabolism $\left(\mathrm{rCMRO}_{2}\right)$ and the regional oxygen extraction ratio (rOER), defined as the relationship between blood flow and oxygen utilization $^{3}$ are given.

\section{Materials and methods}

Ten patients with complex partial seizures were investigated. Initially they were selected because they demons-

Address for reprint requests: Dr MR Trimble, the National Hospital, Queen Sq, London WC1 3BG, UK.

Received 20 January 1983

Accepted 7 February 1983 trated on clinical examination, and had on the EEG, evidence of a temporal lobe focus. In some patients secondary generalisation was known to occur, but the predominant seizure was partial and no patient was examined who had a generalised seizure in the month prior to the scans. A history of epilepsy was present for at least 15 years in all patients. Five had a right sided focus, in three minor abnormalities but no spikes being seen in the contralateral recordings, four a left sided focus and one bilateral independent abnormalities. Basic biographical information is given in table 1 . There were six males and four females with a mean age of 31.5 years (range 19-51). Their IQ was within the normal range (mean 97.1). One patient had cerebellar inco-ordination. All patients had received polytherapy with anticonvulsants, but one patient had no drugs for one year prior to the scan. Conventional CT scans were performed in all patients and were regarded as normal in eight, two showing minor cortical atrophy. For comparison, ten positron scans from age matched normal volunteers were used (mean age 30.5, range 24-49).

The methodology of the scan procedure was as follows. Oxygen-15 was produced by a cyclotron $(\mathrm{t} 1 / 2=2 \cdot 1 \mathrm{~m})$, and during continuous sequential inhalation by the subject of 15-0 labelled carbon dioxide and oxygen, a series of transaxial emission tomograms was taken by a positron emission tomograph (EGG and ORTEC-ECATIIR). In most cases four cuts were examined at $\mathrm{OM}+2,+4,+6$, $+8 \mathrm{~cm}$. All emission data were corrected for attenuation by the corresponding transmission scans, and tracer equations which relate steady state measurements to tissue blood flow and oxygen extraction ratios were used to calculate absolute quantitative values of $\mathrm{rCBF}, \mathrm{rCMRO}_{2}$ and rOER (for full details of the method see Frackowiak et $\mathrm{al}^{3}$ ).

Following a computer print-out of the quantitative data, $2.5 \mathrm{~cm}^{2}$ regions of interest (ROI) were chosen corresponding to the frontal, temporal, posterior temporal and occipi- 
Table 1 Clinical data of the epileptic patients

\begin{tabular}{|c|c|c|c|c|c|c|}
\hline $\begin{array}{l}\text { Patients } \\
\text { ECAT } n^{\circ}\end{array}$ & $\begin{array}{l}\text { Age } \\
(y r)\end{array}$ & Type of seizures & $\begin{array}{l}\text { Neurological } \\
\text { examination }\end{array}$ & $\begin{array}{l}\text { Site of focus } \\
\text { (EEG) }\end{array}$ & $C T$ scan & $\begin{array}{l}\text { Frequency of partial } \\
\text { seizures at the time of } \\
\text { the scan } \\
\text { (per month) }\end{array}$ \\
\hline $\begin{array}{l}170 \\
224 \\
226 \\
298 \\
313 \\
322 \\
331\end{array}$ & $\begin{array}{l}19 \\
31 \\
50 \\
22 \\
46 \\
36 \\
25\end{array}$ & $\begin{array}{l}\text { CPS } \dagger \\
\text { CPS } \\
\text { CPS } \dagger \\
\text { CPS } \dagger \\
\text { CPS } \dagger \\
\text { CPS } \dagger \\
\text { CPS } \ddagger \dagger\end{array}$ & $\begin{array}{l}\text { normal } \\
\text { normal } \\
\text { normal } \\
\text { normal } \\
\text { normal } \\
\text { normal } \\
\text { cerebellar } \\
\text { incoordination }\end{array}$ & $\begin{array}{l}\text { left } \\
\text { right } \\
\text { right } \\
\text { right } \\
\text { bilateral } \\
\text { left } \\
\text { right }\end{array}$ & $\begin{array}{l}\text { normal } \\
\text { normal } \\
\text { normal } \\
\text { normal } \\
\text { cortical atrophy } \\
\text { normal } \\
\text { normal }\end{array}$ & $\begin{array}{r}30 \\
30 \\
0 \\
8 \\
3 \\
1 \\
1\end{array}$ \\
\hline $\begin{array}{l}341 \\
355 \\
335\end{array}$ & $\begin{array}{l}29 \\
22 \\
35\end{array}$ & $\begin{array}{l}\text { CPS† } \\
\text { CPS } \\
\text { CPS† }\end{array}$ & $\begin{array}{l}\text { normal } \\
\text { normal } \\
\text { normal }\end{array}$ & $\begin{array}{l}\text { right } \\
\text { left } \\
\text { left }\end{array}$ & $\begin{array}{l}\text { normal } \\
\text { normal } \\
\text { frontal atrophy }\end{array}$ & $\begin{array}{r}0 \\
4 \\
120\end{array}$ \\
\hline
\end{tabular}

${ }^{*} \mathrm{CPS}=$ complex partial seizures.

†CPS = secondary generalisation known to occur at some time. $\ddagger C P S=$ no anticonvulsant drugs.
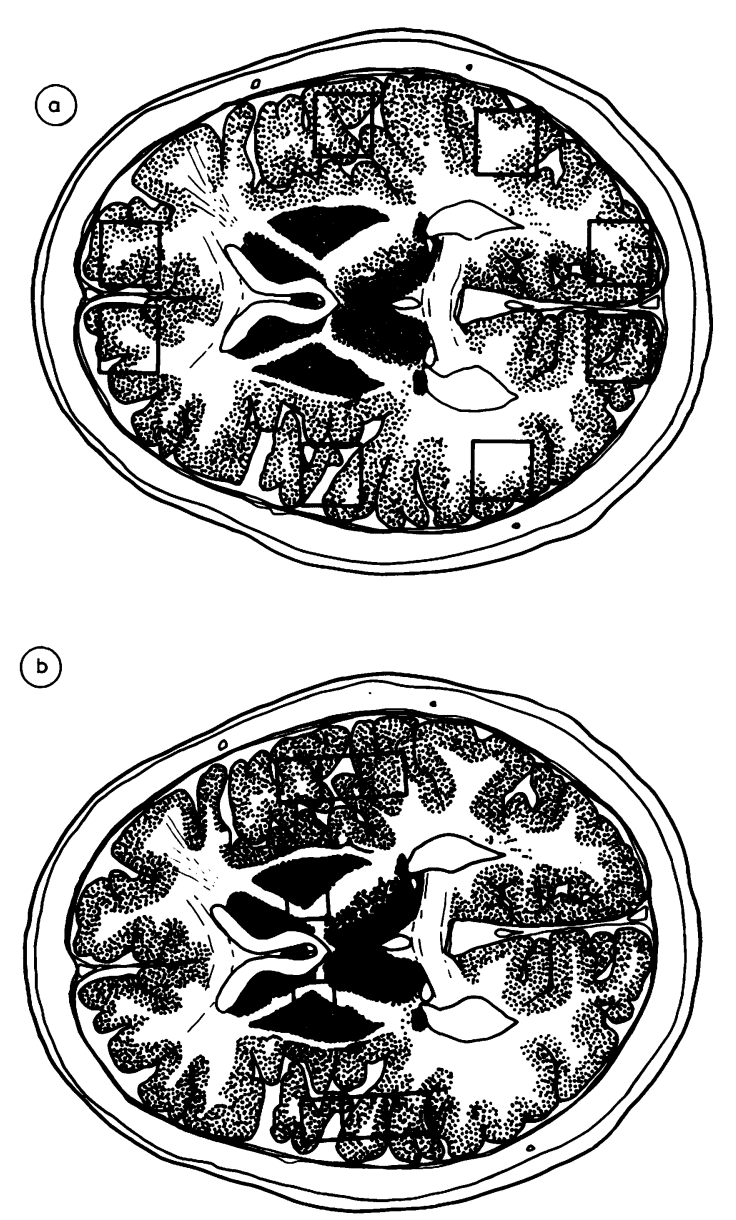

Fig 1 Showing regions of interest in (a) frontal, temporal and occipital lobes; and (b) temporal cortex, examined at slice $O M+4$. tal regions on two slices at $\mathrm{OM}+4$ and $\mathrm{OM}+6$ (Fig 1). A cerebellar region was chosen on the $\mathrm{OM}+2$ slice. Additional areas of $1.5 \mathrm{~cm}^{2}$ were analysed in the temporal cortex and basal ganglia of the patients. Statistical analysis, comparing patients with epilepsy to normal subjects was by Student's $t$ test.

\section{Results}

The mean hemisphere values, assessed by taking the values from both hemispheres at the $O M+4$ slice from frontal, temporal, parietal and occipital areas are shown in table 2. Patients with epilepsy had an $18 \%$ decrease of both $\mathrm{rCBF}$ and $\mathrm{rCMRO}_{2}$ compared with controls.

Regional analysis of the data from frontal, temporal, posterior temporal and occipital areas are shown in table 3 . The posterior temporal areas, temporal lobe, and temporal cortex values are significantly lower in the epileptic patients for $\mathrm{rCMRO}_{2}$. Similar but less significant changes are noted for the rCBF. Values for occipital lobe and frontal lobe are decreased in the epileptic group but with the exception of the $\mathrm{rCMRO}_{2}$ in the frontal lobes, differences do not reach levels of significance. Basal ganglia values are also significantly diminished in the epileptic group $\left(3.5 \mathrm{ml} \mathrm{O} / 100 \mathrm{ml} / \mathrm{m} \mathrm{rCMRO}_{2}\right.$, $38.6 \mathrm{ml} / 100 \mathrm{ml} / \mathrm{m} \mathrm{r} \mathrm{CBF}$ ). The only significant alteration of the rOER was in the temporal cortex $(0.63$ $\mathrm{p}<0.01$ ).

Table 2 Mean hemispheric values of subjects with temporal lobe epilepsy

\begin{tabular}{lcccll}
\hline & \multicolumn{1}{c}{ Epileptics } & Normals & $\%$ & $p$ \\
\hline CMRO $_{2}$ & $3.6 \pm 0.89$ & $4.25 \pm 0.91$ & -18 & $<0.001$ \\
CBF & $38.2 \pm 9.8$ & $45.1 \pm 12.6$ & -18 & $<0.05$ \\
OER $^{2}$ & $0.52 \pm 0.09$ & $0.05 \pm 0.14$ & +4 & NS \\
\hline
\end{tabular}

Values from both hemispheres at $\mathrm{OM}+4$ slice: frontal, temporal parietal and occipital area of $2.5 \mathrm{~cm}^{2}$. 
Table 3 Mean $\mathrm{CMRO}_{2}$ and $\mathrm{CBF}$ and $\mathrm{OER}$ for various brain regions ipsilateral to the side of the $E E G$ focus $(N=10)$

\begin{tabular}{|c|c|c|c|c|c|c|}
\hline \multirow{3}{*}{$\begin{array}{l}\text { Frontal lobe } \\
\text { Temporal lobe } \\
\text { Posterior temporal } \\
\text { region } \\
\text { Temporal cortex } \\
\text { Occipital lobe } \\
\text { Basal ganglia } \\
\text { Cerebellum }\end{array}$} & \multicolumn{2}{|c|}{$\begin{array}{c}\text { Epileptics } \\
\mathrm{CCMRO}_{2}\end{array}$} & Epileptics & Normals & Epileptics & $\mathrm{R}^{\text {Normal }}$ \\
\hline & $\begin{array}{l}3.3 \pm 0.7 \\
3.4 \pm 0.3\end{array}$ & $\begin{array}{l}3.9 \pm 0.7^{*} \\
4 \cdot 1 \pm 0.8 \dagger\end{array}$ & $\begin{array}{l}39.6 \pm 11.8 \\
37.8 \pm 7.8\end{array}$ & $\begin{array}{l}41 \cdot 9 \pm 8 \cdot 7 \\
46 \cdot 3 \pm 14.7\end{array}$ & $\begin{array}{l}0.50 \pm 0.11 \\
0.50 \pm 0.08\end{array}$ & $\begin{array}{l}0.50 \pm 0.10 \\
0.49 \pm 0.09\end{array}$ \\
\hline & $\begin{array}{l}3.1 \pm 0.5 \\
3.5 \pm 0.7 \\
4.6 \pm 0.1 \\
3.5 \pm 0.5 \\
3.9 \pm 0.9\end{array}$ & $\begin{array}{l}4.3 \pm 0.5 \ddagger \\
4.3 \pm 0.7^{*} \\
5.0 \pm 0.9 \\
4.3 \pm 0.9^{*} \\
5.1 \pm 0.0 \ddagger\end{array}$ & $\begin{array}{l}32.3 \pm 5 \cdot 6 \\
37.5 \pm 13.5 \\
42.7 \pm 12.0 \\
38.6 \pm 10.0 \\
40.9 \pm 13.2\end{array}$ & $\begin{array}{l}42.5 \pm 10.7^{*} \\
53.0 \pm 13.8^{*} \\
48.9 \pm 16.3 \\
49.9 \pm 7.9^{*} \\
55.5 \pm 15.3 \ddagger\end{array}$ & $\begin{array}{l}0.52 \pm 0.06 \\
0.63 \pm 0.07 \\
0.55 \pm 0.08 \\
0.50 \pm 0.08 \\
0.53 \pm 0.12\end{array}$ & $\begin{array}{l}0.54 \pm 0.11 \\
0.48 \pm 0.10 \dagger \\
0.57 \pm 0.12 \\
0.46 \pm 0.07 \\
0.53 \pm 0.90\end{array}$ \\
\hline
\end{tabular}

$* \mathrm{p}<0.05$

$+\mathrm{p}<0.01 t$ test

$\ddagger \mathrm{p}<0.001$

Values of the regions in patients chosen at $\mathrm{OM}+4$ from the affected hemisphere $\left(2.5 \mathrm{~cm}^{2}\right)$, including temporal cortex and basal ganglia $\left(1 \cdot 5 \mathrm{~cm}^{2}\right)$. Cerebellum measurements $\left(2 \cdot 5 \mathrm{~cm}^{2}\right)$ taken at $\mathrm{OM}+2$.

Figures are in $\mathrm{ml} / 100 \mathrm{ml} / \mathrm{m}$.

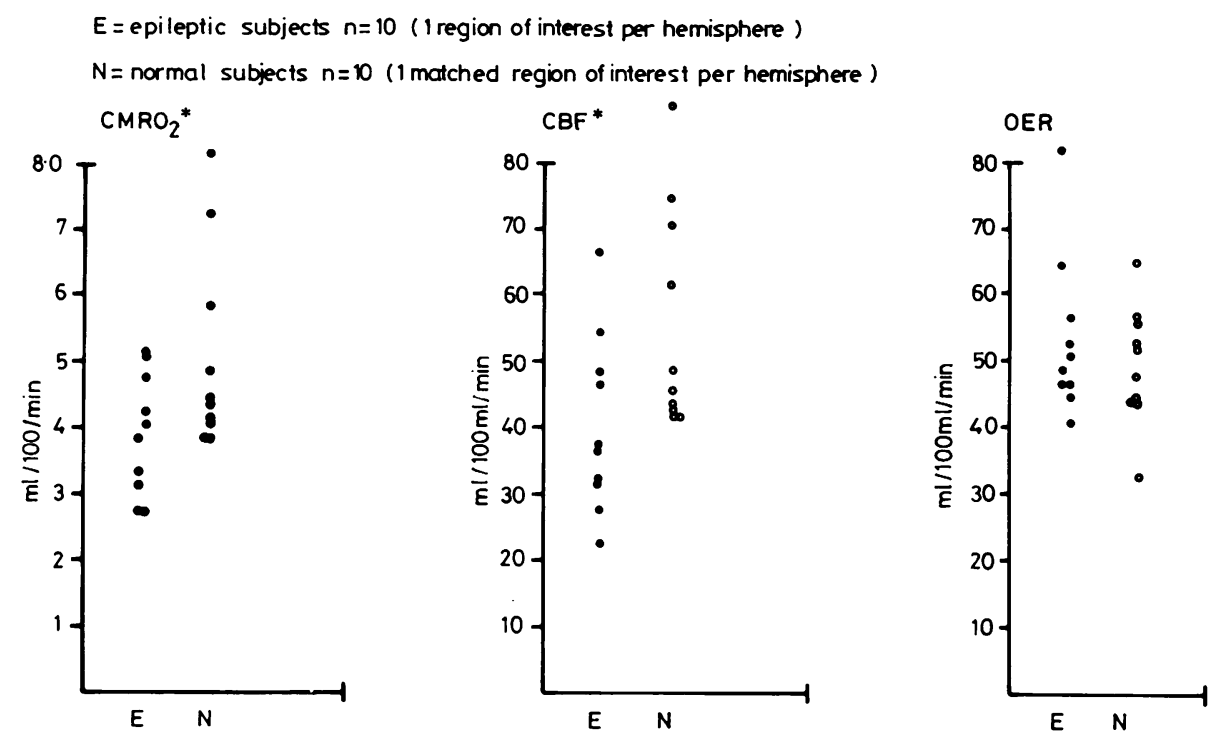

Fig 2 Values of rCMRO, rCBF and rOER in the cerebellum. Patients and non-epileptic controls $\left({ }^{*} p<0.001\right.$ : $t$ test $)$.

Of the nine patients with a unilateral focus, temporal cortex values from the side ipsilateral and contralateral to the focus have been examined separately. There was a lower figure recorded on the side ipsilateral to the focus (CBF-7.6\% ( $p<0.05)$, $\mathrm{rCMRO}_{2}-4.8 \%$ (NS)), which was still present in those six patients with exclusively unilateral abnormalities on the surface EEG. However, compared to controls, even values of the contralateral temporal cortex are diminished. (rCBF 37.8 \pm 11.9 ; $\mathrm{rCMRO}_{2}$ $3 \cdot 6 \pm 0 \cdot 6$ ). The significant difference for the rOER however was not recorded contralaterally. At the level $\mathrm{OM}+6$, the only significant differences noted were a lowered $\mathrm{rCMRO}_{2}$ and $\mathrm{rCBF}$ in the temporal lobes ipsilaterally. $(3.6 \pm 0.6 p<0.05$, and $38.1 \pm$ $7.2 \mathrm{p}<0.05$ respectively). In the age matched controls, no significant differences were noted between the values of the right and left hemispheres. In the cerebellum, rCBF and $\mathrm{rCMRO}_{2}$ were significantly decreased in the epileptic patients $(31 \%$ and $36 \%$ respectively, $p<0.001$ ) (Fig 2). No differences were seen between the hemisphere contralateral and ipsilateral to the focus. The values of $\mathrm{rCMRO}_{2}$ and rCBF for the cerebellum in the patient with clinical cerebellar inco-ordination were $2.8 \mathrm{ml} / 100 \mathrm{ml} / \mathrm{m}$ and $23 \mathrm{ml} / 100 \mathrm{ml} / \mathrm{m}$ respectively. 


\section{Discussion}

In this study of $\mathrm{rCMRO}_{2}$ and $\mathrm{rCBF}$, using positron emission tomography, significant changes have been shown interictally in patients with complex partial seizures. While the hemisphere containing the abnormal focus shows the more marked changes, particularly with respect to $\mathrm{rCMRO}_{2}$ the contralateral hemisphere is also abnormal with respect to normal aged matched controls. Sakai et $a^{4}$, using $x^{x e n o n}{ }^{133}$ inhalation to measure rCBF also noted contralateral changes in individual patients with partial epilepsy during activation procedures, and clearly such findings have relevance for the possibility of the development of a mirror focus.

Our data stand in contrast to those of Kuhl et al ${ }^{1}$ who, using 18-fluoro-2-deoxy-glucose in patients with partial epilepsy, reported focal areas of decreased CMRglu which corresponded to EEG spike foci, but noted the results in the contralateral hemisphere to be "very similar to the distribution found in the normal subjects". In their report, however, two of their seven controls were under 6 years old. Each of our patients was matched for age as closely as possible to a control, and as little data is available as yet on children with epilepsy, the discrepancy between results may be related to suitability of controls in different studies. An alternative explanation may have been patient selection. In this series, patients were referred for positron emission tomography scans if they had a well defined focus on the EEG, although clinically four in this series had psychosis. Many of the patients from the studies of Kuhl et al were being investigated for possible temporal lobectomy, and may therefore be expected to show more regionally defined pathology. Indeed, six of their sample underwent lobectomy and all had pathological lesions in the resected specimen. Interestingly they noted that in these patients "the extent of the metabolic deficit was larger than the extent of the structural damage found at pathological evaluation".

In our regional analysis of the data, the most severely affected areas are in the temporal cortex, especially ipsilateral to the focus, central grey areas and the area defined as the posterior temporal lobe. Differences are far less for the occipital and frontal lobes. Decreased rCBF and $\mathrm{rCMRO}_{2}$ in the ipsilateral temporal grey matter with the suggestion of a high rOER suggest that here, at the site of the focus the reserve of oxygen supply is diminished and the tissue metabolic requirements are high, even interictally. The consequences of this for the development of further cell damage following seizures can, at the present time be only speculative. Nevertheless such data may suggest an increased vulnerability of neurons in the region to decreased perfusion or oxygenisation of the arterial blood during generalised seizure activity.

One of the most interesting findings is the marked disturbance of flow and metabolism seen in the cerebellar hemispheres. This affects both sides and is coupled. Cerebellar atrophy is a well described finding in epilepsy, and has been a subject of controversy with regard to its pathogenesis. While some suggest, based especially on animal data, that it occurs secondary to seizures and a resulting anoxia, ${ }^{5}$ other authors relate this finding to the ingestion of phenytoin. ${ }^{6}$ While six of our patients were on phenytoin, one was on no therapy and two were on carbamazepine monotherapy. The patient with cerebellar signs clinically was free from drugs, but did have very low values of cerebellar $\mathrm{CBF}$ and $\mathrm{CMRO}_{2}$. The mean values of the patients on carbamazepine were $4.4\left(\mathrm{CMRO}_{2}\right)$ and $40.5(\mathrm{CBF})$, higher than the group mean for the $\mathrm{CMRO}_{2}$. Clearly further studies, especially examining drug free patients, are required, as well as investigations on patients with other forms of partial and generalised epilepsy. The findings of cerebellar changes in patients without detectable lesions on conventional CT scans needs further investigation, since data from animal literature $\mathrm{u}^{4}$ showing increased cerebellar blood flow during convulsions, the demonstration of crossed cerebellar diaschisis following strokes ${ }^{7}$ and the data mentioned above, suggest that cerebellar involvment in epilepsy may be more substantial than previously suspected.

\section{References}

${ }^{1}$ Kuhl DE, Engel J, Phelps ME, Selin C. Epileptic patterns of local cerebal metabolism and perfusion in humans determined by emission computed tomography of 18 FDG and $13 \mathrm{NH}_{3}$. Ann Neurol 1980;8:348-60.

${ }^{2}$ Sokoloff L. Localisation of functional activity in the C.N.S. by measurement of glucose utilisation with radioactive deoxyglucose. J Cerebral Blood Flow and Metabolism 1981;1:7-36.

${ }^{3}$ Frackowiak RSJ, Lenzi GL, Jones T, and Heather JD. Quantative measurement of regional cerebal blood flow and oxygen metabolism in man using 150 and positron emission tomography. J Comput Assist Tomogr 1980;4:727-36.

${ }^{4}$ Sakai F, Meyer JS, Naritomi H, Hsu M. Regional cerebral blood flow and EEG in patients with epilepsy. Arch Neurol 1978;35:648-57.

${ }^{5}$ Dam M. Diphenylhydantoin: Neurologic aspects of toxicity. In: Woodbury AM, Percy JK and Smidt RP, eds. Anti-epileptic drugs. Raven Press New York, 1972: 227-35. 
${ }^{6}$ Kokenge R, Kutt H, McDowell F. Neurological sequelae following dilantin overdose in a patient and in experimental animals. Neurology (Minneap) 1965;15:8239.
' Lenzi GL, Frackowiak RSJ, Jones T. Cerebral oxygen metabolism and blood flow in human cerebral ischaemic infarction. J Cerebral Blood Flow and Metabolism 1981;2:321-37. 